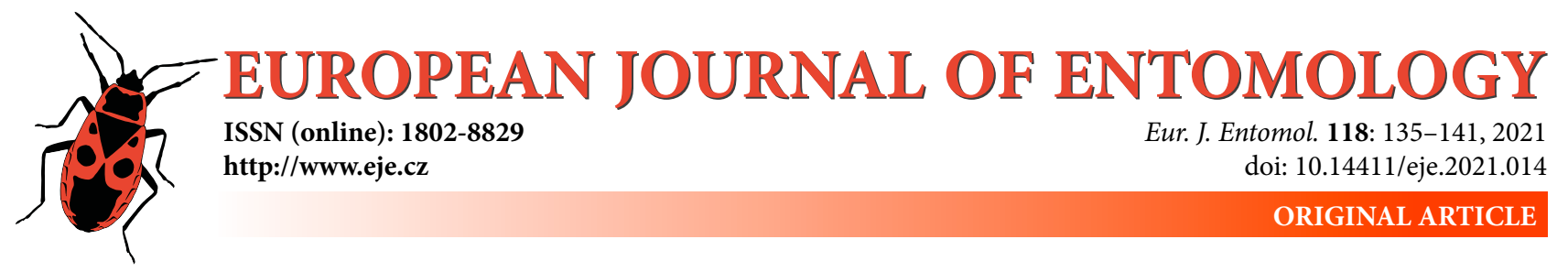

\title{
Effectiveness of inundative releases of Anthocoris nemoralis (Hemiptera: Anthocoridae) in controlling the olive psyllid Euphyllura olivina (Hemiptera: Psyllidae)
}

\author{
NACEUR GHARBI ID \\ Institut de l'Olivier, Laboratory of Integrated Olive Production, Cité Mahrajène, BP 208, 1082 Tunis, Tunisia; \\ e-mail: gharbi.naceur@yahoo.fr
}

Key words. Hemiptera, Anthocoridae, Anthocoris nemoralis, Psyllidae, Euphyllura olivina, olive psyllid, control, inundative releases, olive tree, Tunisia

\begin{abstract}
This study investigated the effectiveness of field releases of nymphs of Anthocoris nemoralis (F.) (Hemiptera: Anthocoridae) in controlling the olive psyllid, Euphyllura olivina Costa (Hemiptera: Psyllidae). Field trials were conducted in two successive years (2014 and 2015) in two organic olive orchards located in the region of Sfax (Tunisia) using two treatments: low (release of 10 A. nemoralis nymphs/tree) and high (release of $40 \mathrm{~A}$. nemoralis nymphs/tree) applied two times, the first on March 3 and second on March 17. In both olive orchards, the high treatment was the most effective in controlling the increase of $E$. olivina in the spring. The A. nemoralis population grew gradually and reached a single peak towards the end of April. In control and low treatment plots, despite the significant increase in predator populations, psylla abundance was not controlled. After the second release, however, in high treatment plots a reduction in psyllid density was recorded. An expected effect of the $A$. nemoralis releases was a reduced parasitic activity of Psyllaephagus euphyllurae (Masi) (Hymenoptera: Encyrtidae).
\end{abstract}

\section{INTRODUCTION}

In Tunisia, olive (Olea europaea L. subsp. europaea) is one of the most important agricultural crops. Olive plantations of about 66 million trees cover about one third of the arable land (ca. 1.7 million hectares). In several arid areas, olives are the only crop and are of great economic and social importance (Debo et al., 2011). Olives are attacked by several insect pests (Jarraya, 2003). Among these pests, the olive psyllid, Euphyllura olivina Costa (Hemiptera: Psyllidae) is the most serious (Ksantini, 2003). During spring, high psyllid populations can affect the vegetative development, fertility and reproduction of olive trees (Prophetou \& Tzanakis, 1976; Arambourg, 1984; Jardak et al., 1985; Saeb et al., 2001; Ksantini et al., 2002; Jardak et al., 2004; Tzanakakis, 2006), causing economic losses of up to $60 \%$ of total production in some Mediterranean Basin countries (Jardak et al., 1985; Tzanakakis, 2006). Outbreaks of olive psyllid populations are associated with new shoot production (Pereira et al., 2013), weather conditions (Chermiti, 1989 ) or decrease in natural enemy populations due to the use of insecticides (Chermiti, 1992; Ksantini et al., 2002). Deltamethrin and dimethoate are the most frequently used to control the olive psyllid, olive fruit fly and olive moth (Ksantini, 2003).
Typically, three generations of olive psyllids occur annually in Tunisia. Oviposition by overwintered adults usually begins in mid-February (Ksantini, 2003). Rapid development leads to high levels of infestation (Chermiti, 1992). The first generation, adults and nymphs, feed on tender plant organs and hide under a white cottony coating. The second generation begins feeding in May but becomes inactive (aestivate) (Johnson, 2009; Alford, 2014). The aestivating olive psyllids hide in cracks in the trunk of the host plant (Zalom et al., 2014). When temperatures become optimal again, usually in September, the olive psyllid nymphs resume activity (Alford, 2014). The third generation of nymphs appears in September and October (Zalom et al., 2014).

Every year in Tunisia, different broad spectrum insecticides are used to control olive fruit fly, olive moth and olive psyllid, which has resulted in ecological and toxicological side effects (Chermiti, 1992). These include environmental contamination, including ground water pollution because vast areas are treated (Jarraya, 2003). The destruction of non-target organisms, especially natural enemies, subsequently results in outbreaks of secondary pests such as black olive scale. The accumulation of insecticide residues in the soil of olive orchards also poses problems (Prophetou \& Tzanakis, 1976; Jardak et al., 1985; Saeb et al., 2001; 
Ksantini et al., 2002; Jardak et al., 2004; Tzanakakis, 2006). Non-insecticide alternatives are needed.

In Tunisia, there are 14 species of natural enemies of $E$. olivina (Ksantini, 2003). The olive psyllid is commonly consumed by several species of generalist predators (Anthocoridae, Chrysopidae, Aranae, Coccinellidae and Miridae) and attacked by many parasitoids, Psyllaephagus euphyllurae (Masi) (Hymenoptera: Encyrtidae), Alloxista eleaphila Silv. (Hymenoptera: Cynipidae), Elasmus sp., (Chermiti, 1989; Ksantini, 2003; Gharbi et al., 2012). These natural enemies have an important role in biological control of olive psyllid (Chermiti, 1989), but their effectiveness markedly depends on climatic conditions and human interventions.

The most abundant predator of psyllids in Tunisian olive orchards is Anthocoris nemoralis (F.) (Hemiptera: Anthocoridae), which makes up $49 \%$ of the total number of the natural enemies (Gharbi et al., 2012). Considered to be a specific predator of psyllids (Anderson, 1962; Solomon et al., 2000), this predator is characterized by its ability to detect psyllid infestations by means of volatiles (Drukker et al., 1995; Scutareanu et al., 1997), high search efficiency (Brunner \& Burts, 1975) and strong numerical response (Trapman \& Blommers, 1992; Gharbi et al., 2011). There are many reports describing its role in the biological control of E. olivina populations (Arambourg \& Chermiti, 1986; Ksantini, 2003). According to Chermiti (1989), in 1985 in the region of Mahdia, A. nemoralis reduced the population of the second generation of E. olivina to such a level that it was not necessary to use pesticides.

Anthocoris nemoralis may provide an alternative to the chemical control of E. olivina as is indicated by the great success of $A$. nemoralis mass releases in pear and pistachio orchards (Rieux et al., 1994; Faivre-D’Arcier et al., 2001; Sigsgaard et al., 2006; Yanik \& Unlu, 2015).

This paper describes results of field trials carried out to quantify the effectiveness of augmentative releases of $A$. nemoralis nymphs in controlling the abundance of $E$. olivina. This study also provides some information on the temporal variation in the abundance of the pest after augmentative releases of $A$. nemoralis. This knowledge on the interaction between these species should help improve the management and result in a better control of the olive psyllid.

\section{MATERIALS AND METHODS}

\section{Orchards}

The areas studied were two olive orchards near Sfax, referred as Taous $\left(35^{\circ} 02^{\prime} 23^{\prime \prime} \mathrm{N}, 10^{\circ} 28^{\prime} 34^{\prime \prime} \mathrm{E}\right)$ and Chaal $\left(34^{\circ} 40^{\prime} 10^{\prime \prime} \mathrm{N}\right.$, $10^{\circ} 20^{\prime} 23^{\prime \prime E}$ ). "Chemlali” was the most prevalent cultivar. Both olive orchards have been managed without using pesticides against pests and diseases, and the soil was ploughed superficially with a scarifier three or four times a year to control weeds. The planting of the olive trees in the Taous orchard was on a $7 \mathrm{~m} \times$ $7 \mathrm{~m}$ grid and the trees were about 10 years old (average height $3.35 \mathrm{~m}$, tree canopy diameter $2.33 \mathrm{~m}$ ) and artificially irrigated. In the Chaal orchard planting depended on natural resources and the trees were about 70 years old (average height $4.83 \mathrm{~m}$, tree canopy diameter $5.67 \mathrm{~m}$ ) and planted on a $24 \mathrm{~m} \times 24 \mathrm{~m}$ grid and entirely dependent on rain.

Both habitats were characterized by mean temperatures ranging from $5.8^{\circ} \mathrm{C}$ (January) to $32.2^{\circ} \mathrm{C}$ (August).

\section{Insect-rearing}

Anthocoris nemoralis was collected from olive orchards near Sfax in 2007. Adults and newly emerged A. nemoralis nymphs were reared in Plexiglas boxes $(25 \times 25 \mathrm{~cm}$, and $10 \mathrm{~cm} \mathrm{high)}$ kept in thermo-cabinets under controlled conditions $\left(22 \pm 1^{\circ} \mathrm{C}\right.$, $75 \pm 5 \%$ H.R, photoperiod 16L : 8D). Between 300 and 500 individuals were maintained in each box and were fed on eggs of the Mediterranean flour moth, Ephestia kuehniella Zeller (Lepidoptera: Pyralidae) and water and sucrose were provided by soaking a piece of gauze $1 \times 1 \mathrm{~cm}$ in water and sucrose (Gharbi et al., 2011). The food was supplied daily in sufficient quantities ( 7 to $10 \mathrm{~g}$ eggs/box) in order to reduce cannibalism.

\section{Predator releases}

The aim of the field trials was to assess the effect of the immature stages of $A$. nemoralis (mixture of nymphs from $2^{\text {nd }}$ to $4^{\text {th }}$ instar) on the abundance of E. olivina. As done previously with ladybird beetles (Iperti, 1999) we released anthocorid nymphs instead of anthocorid adults in order to reduce the risk of emigration from release sites.

The immature stages are active but unable to fly, and are unlike adults that have tendency to leave the olive trees on which they were released and move to other trees. The time between the two releases was two weeks, which is the average time required for the second instar of $A$. nemoralis to reach adulthood (12 to 15 days at $22^{\circ} \mathrm{C}$ ) (Gharbi et al., 2011).

In order to simulate an augmentative release of predators, two treatments were used: low and high, the first consisting of two releases of $10 \mathrm{~A}$. nemoralis nymphs per tree and second of two releases of $40 \mathrm{~A}$. nemoralis nymphs per tree. Control plots where no predators were released allowed us to follow the natural development in the numbers of E. olivina.

In 2014 and 2015, there were two releases of anthocorid nymphs in the orchard plots the first on March 3 and second on March 17. Sigsgaard et al. (2006) and Yanik \& Unlu (2015) suggest that more than one release is necessary in order to maintain high population levels of predators in orchards.

Small Plexiglas boxes $(15 \times 10 \mathrm{~cm}$, and $3 \mathrm{~cm}$ high), without tops, were used for releases. These boxes were placed $1.5 \mathrm{~m}$ above the ground in the foliage of each tree, so that the nymphs could freely disperse in all directions. These boxes were removed before the second release two weeks later, which like the first released either 0, 20 or 80 nymphs per tree. Each tree received the same treatment in both years. One of the objectives of this study is to determine if any of $A$. nemoralis individuals released in the first year survived and reinforced those released in the second year or dispersed following the decrease in the pest population in the first year.

The design of the experiments was a Latin square. In each orchard there were nine plots, with three plots per treatment and sixteen trees in each plot. The distance between different plots was $14 \mathrm{~m}$ and $24 \mathrm{~m}$ in the Taous and Chaal orchards, respectively.

\section{Field sampling}

In 2014 and 2015, E. olivina and A. nemoralis populations were monitored weekly from the beginning of February until the end of May. To estimate population levels of $A$. nemoralis and $E$. olivina, all trees were sampled within a plot, five twigs $(10-15 \mathrm{~cm}$ in length) were randomly collected from each tree. These were taken to the laboratory in cool boxes and immediately examined 

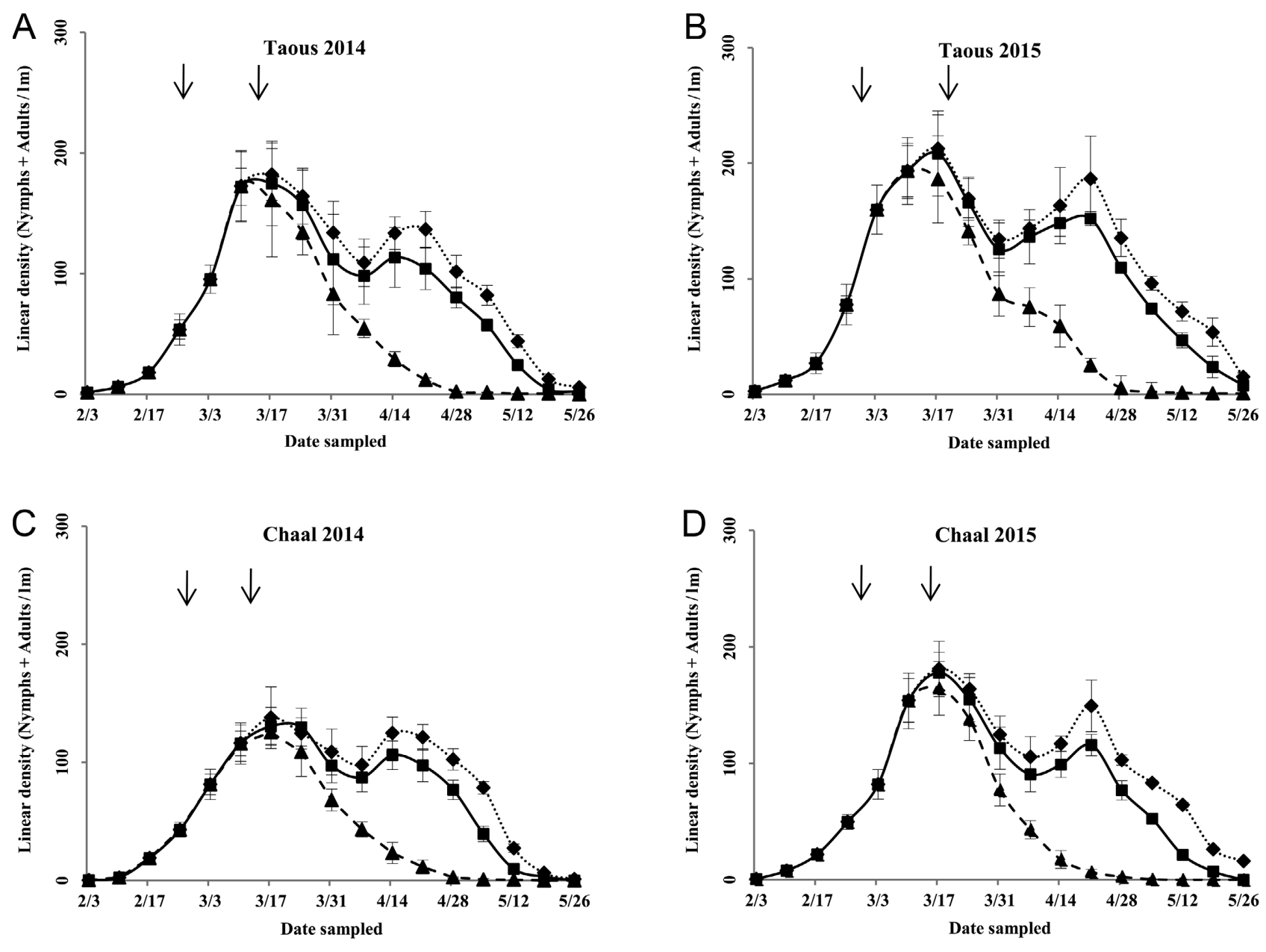

…........... Control

Low treatment

---1-- High treatment

Fig. 1(A-D). Linear densities of Euphyllura olivina (number of nymphs and adults per linear meter of twig) recorded in the orchards at Taous and Chaal, before and after the releases of Anthocoris nemoralis in 2014 and 2015. Black arrows indicate releases on March 3 and March 17. Low treatment: two releases of $10 \mathrm{~A}$. nemoralis nymphs/tree. High treatment: two releases of $40 \mathrm{~A}$. nemoralis nymphs/tree. Control: no predators released.

under stereomicroscope and the different stages (eggs, nymphs and adults) of E. olivina and A. nemoralis counted.

To evaluate the effect of the releases on the abundance of other natural enemies, we recorded the total number of different species of predators present, Chrysoperla carnea (Stephens) (Neuroptera: Chrysopidae) and syrphids, as well as the mummies of E. olivina parasitized by $P$. euphyllurae in the periods after the releases.

\section{Data analysis}

Psyllid numbers were expressed in terms of the numbers of psyllid nymphs (Chermiti, 1989, 1992; Ksantini, 2003) on twigs collected in terms of the number of all stages/linear length in meters $(\mathrm{lm})$. The same approach was adopted for A. nemoralis.

These variables were analysed using an ANOVA (SPSS Inc., 2012). The field data was analysed as repeated measures, where individual samples from a plot were the random variable. Data were transformed using Log-transformation in order to normalize the distribution and homogenize the variance.

The Student t-test was used to compare pairs of treatments. Orchard was treated as a factor.

\section{RESULTS}

In early February, in both orchards, the psyllid populations increased rapidly and reached very high densities, with the first peak around the middle of March. The highest peak was recorded in the control plots in the Taous orchard on March 17, 2015 with a value of 208.41 individuals/lm (Fig. 1B). Then, the population of the pest declined slightly towards the end of March with the minimum recorded between March 31 and April 7. Subsequently, it increased with a second smaller peak between April 14 and April 28.

After the second peak the pest population declined, which was associated with a change in climatic conditions (increase in temperature and decrease in humidity) and lignification of the twigs.

Before the releases of $A$. nemoralis, the linear densities of the olive psyllid E. olivina were 95.44 and 159.88 individuals/lm in the Taous orchard, in 2014 and 2015, respectively (Fig. 1A and B) and 81.31 and 81.86 individuals/lm in 2014 and 2015 in the Chaal orchard, respectively (Fig. $1 \mathrm{C}$ and $\mathrm{D})$. 

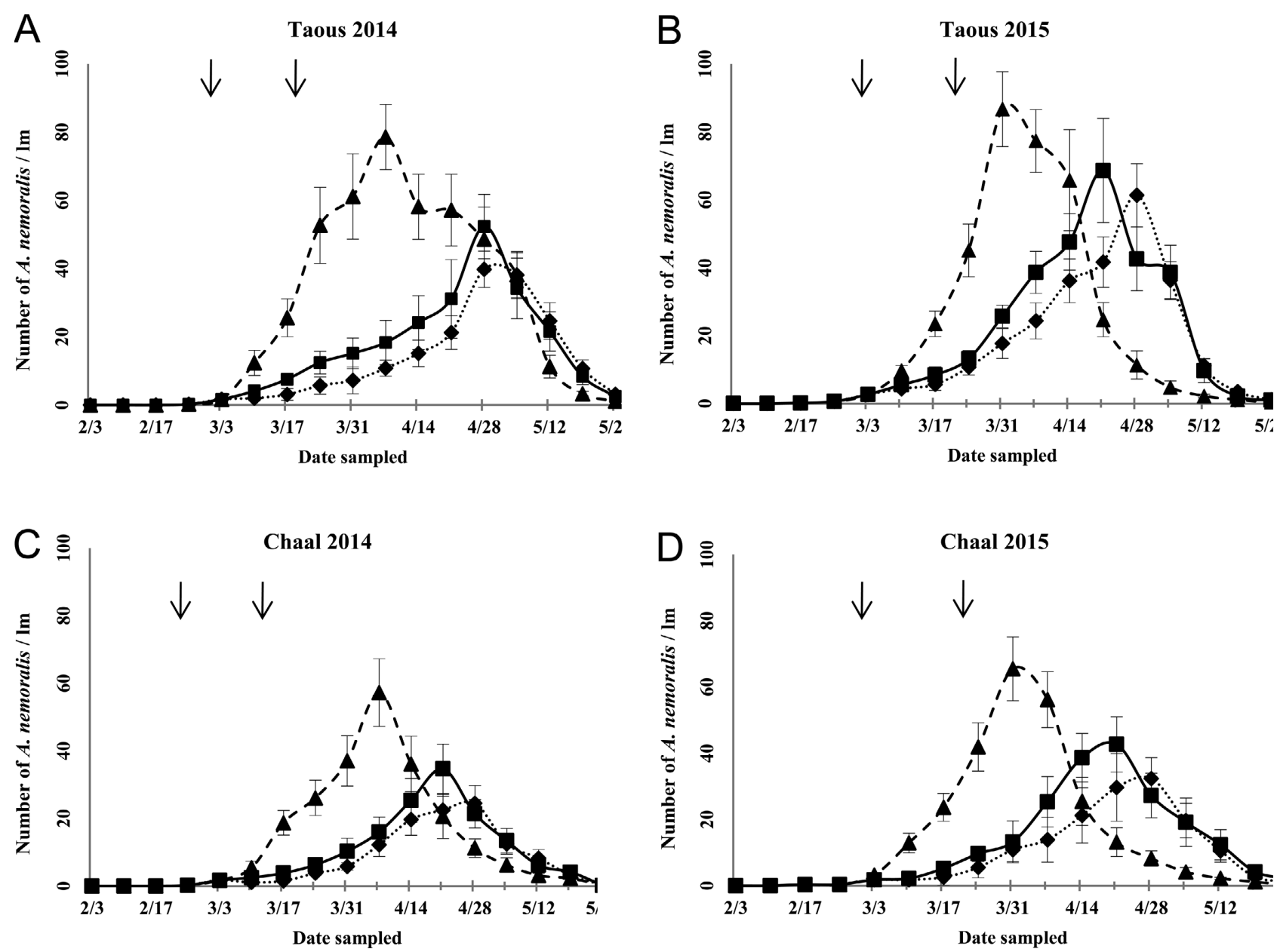

............. Control Low treatment - - - - High treatment

Fig. 2(A-D). Linear densities of Anthocoris nemoralis (number of nymphs and adults per linear meter of twig) recorded in the orchards at Taous and Chaal, before and after releases in 2014 and 2015. Black arrows indicate the releases on March 3 and March 17. Low treatment: two releases of $10 \mathrm{~A}$. nemoralis nymphs/tree. High treatment: two releases of $40 \mathrm{~A}$. nemoralis nymphs/tree. Control: no predators released.

During the first two weeks after the first release, the psylla linear densities continued to increase and were not significantly affected differently in the treatments. One week after the second release an appreciable reduction was recorded in the psylla linear density only in the high treatment, whereas in the control and low treatment plots the densities followed almost similar trends, with slightly lower numbers in the low treatment.

The trends were the same in both the Chaal and Taous orchards, where psyllid linear density in high treatment plots was significantly lower than in low treatment and control plots (Taous 2014: $\mathrm{F}=24.265 ; \mathrm{df}=2,76 ; \mathrm{P}<0.001$; Taous 2015: $\mathrm{F}=41.678 ; \mathrm{df}=2,79 ; \mathrm{P}<0.001 ;$ Chaal 2014: $\mathrm{F}=$ 48.332; $\mathrm{df}=2,77 ; \mathrm{P}<0.001$ and Chaal 2015: $\mathrm{F}=31.527$; $\mathrm{df}=2,77 ; \mathrm{P}<0.001)$. However, there was no difference in the E. olivina linear densities recorded in the control and in low treatment plots. Late in the season there was a marked decline in psyllid densities in all the plots (Fig. 1A and D).

The high treatment was more effective in reducing psyllid linear densities than the low treatment (Taous 2014: $\mathrm{t}=$ 5.187; $\mathrm{df}=34 ; \mathrm{P}<0.001$ and Taous 2015: $\mathrm{t}=6.637 ; \mathrm{df}=$ 34; $\mathrm{P}<0.001$; Chaal 2014: $\mathrm{t}=4.151 ; \mathrm{df}=31 ; \mathrm{P}<0.001$ and Chaal 2015: $\mathrm{t}=4.837$; $\mathrm{df}=33 ; \mathrm{P}<0.001)$. In addition, the linear densities in low treatment plots were lower than in control plots, but not significantly so (Taous 2014: $\mathrm{t}=$ 1.077; $\mathrm{df}=34 ; \mathrm{P}=0.223$ and Taous 2015: $\mathrm{t}=1.607 ; \mathrm{df}=$ $34 ; \mathrm{P}=0.181 ;$ Chaal 2014: $\mathrm{t}=0.571 ; \mathrm{df}=31 ; \mathrm{P}=0.314$ and Chaal 2015: $\mathrm{t}=0.387 ; \mathrm{df}=33 ; \mathrm{P}=0.387$ ).

All interactions are highly significant: orchards * years $(\mathrm{F}=167.912 ; \mathrm{P}=0.006)$, orchards * treatments $(\mathrm{F}=5.428$; $\mathrm{P}=0.156)$ and treatments $*$ years $(\mathrm{F}=1.919 ; \mathrm{P}=0.343)$, only the interaction orchards $*$ treatments $*$ years is not significant $(\mathrm{F}=0.101 ; \mathrm{P}=0.904)$.

In two orchards, $A$. nemoralis was almost absent until the beginning of March, even in the second year of the experiment. In the control plots, they gradually increased and peaked in abundance towards the end of April, which is when as usual the pest population began to decline.

Before the first release, $A$. nemoralis was present at low densities of between 0 and 1 individuals/ $/ \mathrm{m}$. Then, they gradually increased in abundance as the psylla population increased throughout the season.

After the releases, the same scenario was recorded in all orchards, where there was a rapid increase in predator den- 
sity in high treatment plots, which peaked around March 31 or April 7. In the low and control treatment plots, predator populations increased slowly and peaked two to four weeks later.

After March 31, the anthocorid populations consisted mainly of recently laid eggs and hatched nymphs. The highest densities of predators were recorded in high treatment plots (Taous 2014 $=78.55 \pm 9.53$, Chaal $2014=57.23$ \pm 9.99 , Taous $2015=86.66 \pm 11.04$ and Chaal $2015=$ $65.47 \pm 9.65)$, followed by low treatment plots and finally the control plots.

The increase in predator number was significantly higher in high treatment plots than in the other plots (Taous 2014: $\mathrm{F}=64.216 ; \mathrm{df}=2,76 ; \mathrm{P}<0.001 ;$ Taous 2015: $\mathrm{F}=77.618$; df $=2,79 ; \mathrm{P}<0.001 ;$ Chaal 2014: $\mathrm{F}=34.611 ; \mathrm{df}=2,77 ; \mathrm{P}$ $<0.001$; and Chaal 2015: $\mathrm{F}=18.366 ; \mathrm{df}=2,77 ; \mathrm{P}<0.001)$.

Despite the significant increase in predator densities it was insufficient to control psylla numbers below damaging levels in control and low treatment plots (Fig. 2A-D).

In 2015 , the psyllid population developed in a similar way as in 2014 with the $A$. nemoralis population beginning from zero. Hence the releases made during the year 2014 have no effect on the predator population the following year.

Table 1 shows the total numbers of the most abundant of E. olivina natural enemies. It is noteworthy that the total number of $A$. nemoralis collected was highest in the plots in which there were releases. The increase in abundance of $A$. nemoralis had no effect on the numbers of lacewings and syrphids. Their increase in abundance, however, was associated with a reduction in mummified larvae of psyllids and subsequently of the parasitoid P. euphyllurae.

Table 1. Total number and percentage make up of the insect natural enemies recorded in the release and control plots in orchards at Taous and Chaal in 2014 and 2015. Period sampled: February-May.

\begin{tabular}{|c|c|c|c|c|c|c|}
\hline \multirow{2}{*}{$\begin{array}{l}\text { Insect species } \\
\text { Sampling year }\end{array}$} & \multicolumn{2}{|c|}{ Control } & \multicolumn{2}{|c|}{$\begin{array}{c}\text { Low } \\
\text { treatment }\end{array}$} & \multicolumn{2}{|c|}{$\begin{array}{c}\text { High } \\
\text { treatment }\end{array}$} \\
\hline & $\begin{array}{c}\text { Total } \\
\text { number }\end{array}$ & $\%^{a}$ & $\begin{array}{c}\text { Total } \\
\text { number }\end{array}$ & $\%$ & $\begin{array}{c}\text { Total } \\
\text { number }\end{array}$ & $\%$ \\
\hline \multicolumn{7}{|l|}{$\begin{array}{l}\text { Chaal } \\
2014\end{array}$} \\
\hline Anthocoris nemoralis & 919 & 50.88 & 1266 & 61.33 & 4456 & 88.62 \\
\hline Psyllaephagus euphyllurae & 546 & 30.23 & 486 & 23.54 & 231 & 4.59 \\
\hline Chrysoperla carnea & 311 & 17.22 & 288 & 13.95 & 309 & 6.14 \\
\hline $\begin{array}{l}\text { Syrphid predators } \\
2015\end{array}$ & 30 & 1.66 & 24 & 1.16 & 32 & 0.64 \\
\hline Anthocoris nemoralis & 1069 & 49.10 & 1431 & 60.20 & 4633 & 87.64 \\
\hline Psyllaephagus euphyllurae & 603 & 27.69 & 542 & 20.80 & 209 & 3.95 \\
\hline Chrysoperla carnea & 4612 & 21.17 & 366 & 15.39 & 386 & 7.30 \\
\hline Syrphid predators & 44 & 2.02 & 38 & 1.59 & 58 & 1.09 \\
\hline \multicolumn{7}{|l|}{ Taous } \\
\hline Anthocoris nemoralis & 1133 & 58.16 & 1306 & 60.94 & 5166 & 90.93 \\
\hline Psyllaephagus euphyllurae & 506 & 25.97 & 463 & 21.60 & 221 & 3.89 \\
\hline Chrysoperla carnea & 264 & 13.55 & 321 & 14.98 & 266 & 4.68 \\
\hline $\begin{array}{l}\text { Syrphid predators } \\
2015\end{array}$ & 45 & 2.31 & 53 & 2.47 & 28 & 0.49 \\
\hline Anthocoris nemoralis & 1204 & 62.61 & 1477 & 67.26 & 5580 & 91.70 \\
\hline Psyllaephagus euphyllurae & 444 & 23.09 & 385 & 17.53 & 216 & 3.55 \\
\hline Chrysoperla carnea & 222 & 11.54 & 264 & 12.02 & 233 & 3.83 \\
\hline Syrphid predators & 53 & 2.76 & 70 & 3.19 & 56 & 0.92 \\
\hline
\end{tabular}

a $\%=($ Total number of insect $\times 100) /$ Total number of natural enemies collected.
The decrease in the number of psyllid nymphs parasitized by $P$. euphyllurae with increase in the number of A. nemoralis, seems to indicate an inverse relationship between these two natural enemies. The presence of a large number of generalist predators appears to have adversely affected parasitoid fitness and the target herbivore populations. When $A$. nemoralis was present along with $P$. euphyllurae there was a great reduction in the cumulative number of hosts parasitized.

\section{DISCUSSION}

In both of the years studied the E. olivina infestations were higher at Taous than Chaal. It is likely that the climatic conditions (near the sea) and irrigation at Taous were more favourable for the psyllid, which confirms the results of Chermiti (1989) and Ksantini (2003).

Every year, there were two peaks in the populations of psyllids: the first and more important, peak was in the middle of March and the second peak at the end of April.

Yayla (1983) and Gharbi et al. (2012) report that $A$. nemoralis is the most voracious predator of E. olivina. At the beginning of March, this predator was very rare on olive trees and only started to increase gradually from midMarch, peaking at the end of April, slightly later than that of $E$. olivina. The population of $A$. nemoralis is the major part of the overall predator population found on olive tree in the spring (Gharbi et al., 2012).

Anthocoris nemoralis arrives late and in such low numbers that it is unable to control olive psyllid populations before they damage the crop (Chermiti, 1989, 1992). This was also the case in the second year of the study. The failure of $A$. nemoralis to become established is attributed, partly to its annual migration to orchards from hedgerows, where it builds up its population in spring by feeding on psyllids and other arthropods (Scutareanu et al., 1999). Nevertheless, because of their late migration to crops, their numerical response is often insufficient to prevent damage by psyllids (Sarasua et al., 1994; Vilajeliu et al., 1998; Scutareanu et al., 1999; Erler, 2004).

Reports of releasing anthocorids in fields to control psyllids are very scarce. In Europe, Anthocoris has been successfully used against pear psyllids (Sigsgaard et al., 2006). In olive orchards, this study showed that the release of a low number of $A$. nemoralis (20 nymphs/tree) was insufficient to control the olive psyllid, but release of a high number ( 80 nymphs/tree) was followed by an increase in the number of $A$. nemoralis offspring and a significant suppression of the target herbivore population.

Field releases of anthocorids is an efficient method of controlling the spring build-up of the E. olivina population and keeping it at an acceptable level. Early releases increased the overall effect of the natural enemies at a crucial time (flowering period), which is a pre-requisite for successful biological control in olive orchards.

The effect of anthocorids was reinforced by the activity of the other natural enemies present in the orchards. Every year, P. euphyllurae was present especially between mid April and mid May after which it markedly decreased 
in abundance from beginning of May when no psyllid nymphs are present (Gharbi et al., 2012). The number of $A$. nemoralis was highest in treated plots, whereas the number of psylla nymphs parasitized by $P$. euphyllurae was highest in control plots. This inverse relationship between $A$. nemoralis and $P$. euphyllurae could be due to the fact that $A$. nemoralis feeds on nymphs parasitized by $P$. euphyllurae, which indicates that generalist predators can reduce the effectiveness of parasitoids, as previously reported by Yanik \& Unlu (2015).

This interaction between a generalist predator and a specialist parasitoid is an example of a non-additive effect of natural enemies on psyllid populations and is similar to such interactions reported in earlier studies (Colfer \& Rosenheim, 1995, 2001; Ferguson \& Stiling, 1996; Lucas et al., 1998; Snyder \& Ives, 2001; Erbilgin et al., 2004). It is likely that the rate of encounter of $A$. nemoralis with parasitized hosts is very high because they are very mobile (Agarwala et al., 2003). In fact, the high abundance of $A$. nemoralis on the psyllid-infested olive trees may indicate that the competitive ability of $A$. nemoralis in this guild is very high. Rapid maturation of adults, short pre-oviposition period and nymphal development time, and non-discriminatory mating behaviour (Anderson, 1962; Horton et al., 2000) ensure that $A$. nemoralis can successfully compete with $P$. euphyllurae for the same resource.

Augmentative releases of the immature stage of $A$. nemoralis in orchards resulted in significant reductions in psyllid densities. The release of high numbers of adult $A$. nemoralis is currently widely used and can result in good control. But their effect depends on proper timing (availability of prey) and no application of insecticides according to Faivre-D'Arcier et al. (2001). The release of immature stages rather than adults is more effective because nymph dispersal is limited and a quicker effect can be achieved than would result from using anthocorid eggs (Sigsgaard et al., 2006). Indeed, nymphs are preferred over eggs' (Rieux et al., 1994) because the high temperatures in South Eastern part of Tunisia can desiccate anthocorid eggs.

Overall, our study presents a basis for future studies on biological control in olive groves. Further studies on interand intra-guild interactions should be carried out before deciding to release generalist predators to control psyllid infestations in olive orchards. In addition, factors affecting tree health and yield of olive trees should be elucidated

ACKNOWLEDGEMENTS. We thank M. Ghorbel and C. Saadaoui for invaluable technical assistance at various stages of this work. We also thank J. Madiouni for a critical review of the manuscript. This research was financed by the Olive Tree Institute.

DISCLOSURES. No conflicts of interest, financial or otherwise, are declared by the author.

\section{REFERENCES}

Agarwala B.K., Bardhanroy P., Yasuda H. \& Takizawa T. 2003 Effects of conspecific and heterospecific competitors on feeding and oviposition of a predatory ladybird: a laboratory study. —Entomol. Exp. Appl. 106: 219-226.
Alford D.V. 2014: Pests of Fruit Crops: A Colour Handbook. 2nd ed. CRC Press, London, $462 \mathrm{pp}$.

Anderson N.H. 1962: Growth and fecundity of Anthocoris spp. reared on various prey (Heteroptera: Anthocoridae). - Entomol. Exp. Appl. 5: 40-52.

Arambourg Y. 1984: La fauna entomologica del olivo. - Olivae 4: 14-21.

Arambourg Y. \& Chermiti B. 1986: Euphyllura olivina Costa (Hom. Psyllidae). In Arambourg Y. (ed.): Traité d'Entomologie Oléicole. Conseil Oléicole International, Madrid, pp. 163-171.

BRUNNER J.F. \& BuRTs E.C. 1975: Searching behavior and growth rates of Anthocoris nemoralis (Hemiptera: Anthocoridae), a predator of the pear psylla, Psylla pyricola. - Ann. Entomol. Soc. Am. 68: 311-315.

Chermiti B. 1989: Dynamique des populations du psylle de l'olivier Euphyllura olivina, en conditions méditerranéennes. $\mathrm{PhD}$ thesis, Université Aix Marseille, $165 \mathrm{pp}$.

Chermiti B. 1992: Approche d'évaluation de la nocivité du psylle de l'olivier Euphyllura olivina (Costa) (Homoptera, Aphalaridae). - Olivae 43: 34-42.

COLFer R.G. \& Rosenheim J.A. 1995: Intraguild predation by coccinellid beetles on an aphid parasitoid, Lysiphlebus testaceipes. In: Cotton Insect Research and Control. Proceedings of the Beltwide Cotton Conference held January 4-7, 1995, San Antonio, Texas. Vol. 2. pp. 1033-1036.

Colfer R.G. \& Rosenheim J.A. 2001: Predation on immature parasitoids and its impact on aphid suppression. - Oecologia 126: $292-304$.

Debo A., Yangui T., Dhouib A., Ksantini M. \& Sayadi S. 2011: Efficacy of a hydroxytyrosol-rich preparation from olive mill wastewater for control of olive psyllid, Euphyllura olivina, infestations. - Crop Prot. 30: 1529-1534.

Drukker B., Scutareanu P. \& Sabelis M.W. 1995: Do anthocorid predators respond to synomones from Psylla-infested pear trees under field conditions? - Entomol. Exp. Appl. 77: 193-203.

Erbilgin N., Dahlsten D.L. \& Chen P. 2004: Intraguild interactions between generalist predators and an introduced parasitoid of Glycaspis brimblecombei (Homoptera: Psylloidea). — Biol. Contr. 31: 329-337.

ERLER F. 2004: Natural enemies of the pear psylla Cacopsylla pyri in treated vs untreated pear orchards in Antalya, Turkey. - Phytoparasitica 32: 295-304.

Faivre-D'Arcier F., Millot P. \& Belzunces L.P. 2001: Lâchers inoculatifs d'Anthocoris nemoralis en verger de poiriers. Phytoma 544: 76-78.

FERgUSON K.I. \& StiLing P. 1996: Non-additive effects of multiple natural enemies on aphid populations. - Oecologia 108: 375-379.

Gharbi N., Debo A. \& Dhouib H. 2011: Effets des régimes alimentaires sur certains paramètres biologiques de la punaise prédatrice Anthocoris nemoralis (Fabricus) 1794 (Hemiptera: Heteroptera, Anthocoridae). - Rev. Inst. Nat. Agron. Tunis 26: $31-41$.

Gharbi N., Debo A. \& Ksantini M. 2012: Observation of arthropod populations during outbreak of olive psyllid Euphyllura olivina in tunisian olive groves. - Tunis. J. Plant Prot. 7: 35-42.

Horton D.R., Hinojosa T. \& Lewis T.M. 2000: Mating preference, mating propensity, and reproductive traits in Anthocoris nemoralis (Heteroptera: Anthocoridae): a comparison of California and United Kingdom populations. - Ann. Entomol. Soc. Am. 99: 663-672.

IPERTI G. 1999: Biodiversity of predaceous coccinellidae in relation to bioindication and economic importance. - Agric. Ecosyst. Environ. 74: 323-342. 
Jardak T., Moalla M., Khalfallah H. \& SMiri H. 1985: Essais d'évaluation des dégâts causés par le psylle de l'olivier Euphyllura olivina (Homoptera: Psyllidae), données préliminaires sur le seuil de nuisibilité. In: Integrated Pest Control in OliveGroves. Proceeding of the International Joint Meeting, 3-6 April 1984. CEC/FAO/IOB, Pisa, pp. 270-284.

Jardak T., Jarraya A. \& Mahjoub M. 2004: La Protection Intégrée de l'Oléiculture dans les Pays de l'Afrique du Nord. SNEA, Tunis, $120 \mathrm{pp}$.

JarraYA A. 2003: Principaux Nuisibles des Plantes Cultivées et des Denrées Stockées en Afrique du Nord: Leur Biologie, leurs Ennemis Naturels, leurs Dégâts, leur Contrôle. Climat Publications, Tunis, $415 \mathrm{pp}$.

Johnson M.W. 2009: Olive psyllid, Euphyllura olivina (Costa) (Hemiptera: Psyllidae). Center for Invasive Species Research, University of California, Riverside. URL: https://cisr.ucr.edu/ invasive-species/olive-psyllid (last accessed December 2019).

Ksantini M. 2003: Contribution à l'Etude de la Dynamique des Populations du Psylle de l'Olivier Euphyllura olivina (Costa) (Homoptera - Sternorhyncha - Aphalaridae) et de sa Nuisibilité dans la Région de Sfax. PhD thesis, Faculté des Sciences, Sfax, $344 \mathrm{pp}$.

KsANTINI M., JARDAK T. \& BouAIN A. 2002: Temperature effect on the biology of Euphyllura olivina Costa. - Acta Hortic. 586: 827-830.

Lucas E., Coderre D. \& Brodeur J. 1998: Intraguild predation among aphid predators: characterisation and influence of extraguild prey density. - Ecology 79: 1084-1092.

Pereira J.M., Baldin E.L.L., Soliman E.P. \& Wilcken C.F. 2013: Attractiveness and oviposition preference of Glycaspis brimblecombei Moore in Eucalyptus spp. - Phytoparasitica 41: $117-124$

Prophetou D.A. \& Tzanakis M.E. 1976: Seasonal development and number of generations of Euphillura olivina Costa in Halkidiki. — Ann. Entomol. Soc. Am. 70: 707-709.

Rieux R., Fauvel G., Faivre-D’Arcier F., Fournage G. \& LyousSOUFI A. 1994: Study of biological control against Cacopsylla pyri (L.) in pear orchards by experimental release of Anthocoris nemoralis $\mathrm{F}$. in the egg stage. II. Results and discussion. IOBC/WPRS Bull. 17: 120-124.

Saeb H., Moheisani A. \& Nouri H. 2001: Effects of some insecticides on overwintering adults of olive psylla, Euphylura olivina Costa (Hom., Aphalaridae) in Guilan province. - $J$. Agric. Sci. 7: 15-22.

Sarasua M.J., Solà N., Artigues M. \& Avilla J. 1994: The role of Anthocoridae in the dynamics of Cacopsylla pyri populations in a commercial orchard without pesticides. - IOBC/ WPRS Bull. 17: 138-141.
Scutareanu P., Drukker B., Bruin J., Posthumus M.A. \& Sabelis M.W. 1997: Volatiles from psylla-infested pear trees and their possible involvement in attraction of anthocorid predators. J. Chem. Ecol. 23: 2241-2260.

Scutareanu P., Lingeman R., Drukker B., Bruin J. \& Sabelis M.W. 1999: Cross-correlation analysis of fluctuations in local populations of pear psyllids and anthocorid bugs. - Ecol. Entomol. 24: 354-362.

Sigsgaard L., Esbjerg P. \& Philipsen H. 2006: Experimental releases of Anthocoris nemoralis F. and Anthocoris nemorum (L.) (Heteroptera: Anthocoridae) against the pear psyllid $\mathrm{Ca}$ copsylla pyri L. (Homoptera: Psyllidae) in pear. - Biol. Contr. 39: 87-95.

SNYDER W.E. \& Ives A.R. 2001: Generalist predators disrupt biological control by a specialist parasitoid. - Ecology 82: 705-716.

Solomon M.G., Cross J.V., Fitzgerald J.D., Campbell C.A.M., Jolly R.L., Olszak R.W., NiemczyK E. \& Vogt H. 2000: Biocontrol of pests of apples and pears in Northern and Central Europe-3, Predators. - Biocontr. Sci. Technol. 10: 91-128.

SPSS INC. 2012: SPSS 20 for Windows. SPSS Inc., Chicago, IL. URL: https://www.ibm.com/support/pages/downloading-ibmspss-statistics-20

Trapman M. \& Blommers L. 1992: An attempt to pear sucker management in the Netherlands. - J. Appl. Entomol. 114: $38-51$.

TzanaKakis M.E. 2006: Insects and Mites Feeding on Olive: Distribution, Importance, Habits, Seasonal Development and Dormancy. Brill, Leiden, 182 pp.

Vilajeliu M., Vilardell P. \& Lloret P. 1998: Dinámica poblacional de la psila (Cacopsylla pyri L.) y de sus enemigos naturales en plantaciones comerciales de peral de Girona. - Bol. Sanid. Veget. Plagas 24: 231-238.

YANIK E. \& UNLU L. 2015: Initial study of rearing and release of Anthocoris minki Dohrn (Hemiptera: Anthocoridae) for biological control of Agonoscena pistaciae Burckhardt and Lauterer (Hemiptera: Psyllidae) in pistachio orchards. - Agric. Forest. 61: 347-358.

YAYLA A. 1983: Investigation on the olive pests and its natural enemies on the Antalya. - Plant Prot. Bull. 23: 88-206.

Zalom F.G., Vossen P.M. van Steenwyk R.A. \& Johnson M.W. 2014: UC Pest Management Guidelines: Olive Psyllid. Statewide Integrated Pest Management Program. University of California Agriculture and Natural Resources. URL: https://www2. ipm.ucanr.edu/agriculture/olive/Olive-psyllid/

Received August 11, 2020; revised and accepted December 30, 2020 Published online April 30, 2021 